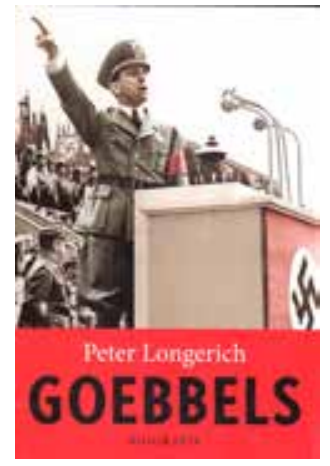

\section{Peter Longerich}

Goebbels, een biografie

Amsterdam (De Bezige Bij), 20I2, 928 p., ill., $€$ 59,90,

ISBN 9789023465034

(vert: Pieter Streutker \& Marten de Vries)

(www.debezigebij.nl/web/Webshop-detailpagina.

htm? ean=9789023465034)

Voor deze lijvige biografie van de Duitse propagandaminister Joseph Goebbels (I897-I945) baseerde Peter Longerich zich vooral op de dagboeken die Goebbels aanvankelijk zelf met de hand schreef, maar gedurende de laatste oorlogsjaren dicteerde en van extra documentatie liet voorzien. Die dagboeken zijn al tientallen jaren bekend en in de loop der jaren herhaaldelijk fragmentarisch gepubliceerd, maar werden pas na de Koude Oorlog volledig gereconstrueerd (op basis van glasnegatieven die zich in Moskou bevonden) en onder auspiciën van Elke Fröhlich, verbonden aan het Institut für Zeitgeschichte (München), in een wetenschappelijke editie op de markt gebracht.

De dagboeken beslaan, inclusief de in aparte volumes uitgebrachte indexen, 32 boekbanden en vormen een fantastische bron, waar vanzelfsprekend voorzichtig mee moet worden omgegaan. Longerich besteedt hier in zijn introductie (pp. I-I8) terecht uitgebreid aandacht aan en verklaart hoe Goebbels, die al in I923 met een dagboek begon, aanvankelijk zeer openhartig en zelfkritisch was, maar zijn dagboek, naarmate zijn politieke carrière vorm kreeg en een hoge vlucht nam, steeds meer omvormde tot een basisdocument voor later te publiceren memoires. De dagboeken, waarvoor Goebbels in I936 een publicatiecontract met Max Amann ondertekende, dienden te getuigen van zijn onberispelijke nationaalsocialistische levenshouding en zijn succesvolle carrière in het 'Derde Rijk'. Ze dienen dus ook vanuit dat perspectief geïnterpreteerd en gedeconstrueerd te worden.

Longerich, die bij de voorbereiding van dit boek uitgebreid met 'een groep Hamburgse psychoanalytici' overlegde 'over de persoonlijkheid van de hoofdpersoon' (p. 725) beschouwt Goebbels als een 'narcistisch gestoorde persoonlijkheid', boven alles gedreven door een 'narcistische zucht naar erkenning' (p. I3). Zijn biografie leest als een lange en overtuigende bewijsvoering voor die stelling.

De auteur heeft zich door de vele duizenden dagboekpagina's geploegd en deze gekoppeld aan de ruime literatuur, waar Longerich uiterst goed mee vertrouwd is, over nazi-Duitsland. De auteur komt op basis daarvan tot een interessant portret, waarin hij enerzijds bekende verhaallijnen uitzet, maar anderzijds eigen accenten legt of nieuwe informatie aandraagt. Zo gaat Longerich relatief uitgebreid in op de door hem ontdekte, en bij het verschijnen van de biografie gretig door de pers onder de aandacht gebrachte, driehoeksrelatie die in I93I ontstond tussen Goebbels, zijn kersverse vriendin Magda Quandt en zijn partijleider en idool Adolf Hitler (pp. I73-I77). De Führer, eenmaal door Goebbels voorgesteld aan Magda, bleek de jongedame uiterst aardig te vinden en ontpopte zich tot een liefdesrivaal. Uiteindelijk kwam men tot een verstandhouding: 'Magda Quandt werd de vrouw die Hitler met haar vlotheid, smaak en raad terzijde moest staan, en zo ongeveer de rol van de first lady in de nazibeweging moest spelen, maar tegelijkertijd naar buiten toe door haar huwelijk met Goebbels in erotisch opzicht geneutraliseerd leek. Op zijn beurt onderdrukte Goebbels zijn jaloezie en schikte zich in het arrangement, dat hem tenslotte onvermoede invloed op Hitler beloofde te geven' (p. I76). Dit alles lijkt plausibel, maar de lezer vraagt zich natuurlijk af hoe die relatie evolueerde nadat Hitlers relatie met Eva Braun, die hij toen al kende, ernstiger werd. Longerich onderneemt echter geen enkele poging om die vraag op te werpen, laat staan te beantwoorden. 
Dit thema vormt immers een blinde vlek - of een van de vele blinde vlekken - in Goebbels' dagboeken. De dagboeken vormen zo de sterkste maar ook de zwakste schakel van Longerichs werk. Wat Goebbels niet noteerde of dicteerde, of wat niet in de reeds beschikbare literatuur geanalyseerd wordt, komt ook niet aan bod.

Goebbels, een biografie is een uiterst leesbaar boek, geschreven door een van de belangrijkste hedendaagse historici van het 'Derde Rijk'. Wie zich in het leven en de carrière van de propagandaminister wil verdiepen, vindt in dit boek een uitmuntende analyse, vergelijkbaar met de biografie van Heinrich Himmler die dezelfde auteur een paar jaar geleden afleverde (Bezige Bij, 2009). Wie de ruimere biografische context minder interessant vindt en vooral geïnteresseerd is in de mediahistorische kant van het verhaal en in een analyse van de mediapolitiek van Goebbels en zijn medewerkers, zal in dit werk echter niets nieuws vinden. Filmhistorici zijn op dat vlak beter af met Der Filmminister (1998, in 2000 vertaald als The Film Minister) van Felix Moeller, die pionierswerk verrichte en jaren voor het Institut für Zeitgeschichte de dagboekindexen publiceerde en alle delen doornam om Goebbels' filmpolitiek te analyseren.

Roel Vande Winkel 